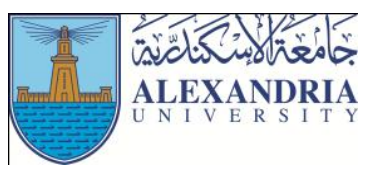

\title{
Designing Objectives and Intended Learning Outcomes of the Handball Course at the Faculty of Physical Education at Al-Azhar University
}

\author{
Al-Sayed Abdul Aziz Al-Sayed Essa ${ }^{1}$, Hosam El Deen Nabeeh Abdul Fattah ${ }^{1}$ \\ ${ }^{1}$ Assistant Prof. of course and Instruction, Faculty of Physical Education - Al-Azhar University, Egypt
}

\begin{abstract}
:
This study aimed at designing the objectives and the intended learning outcomes of the handball course in the light of the integrativetechnique for the students specialized in "optional handball" at the Faculty of Physical Education, Al-Azhar University, and to achieve this goal, The researchers adopted the descriptive course based on the survey because it is the most appropriate for the nature of the research and its objectives and questions, the sample of study consisted of (10 participants) from the experts specialized in course, instruction and handball at the faculties of physical education in Egypt universities, and the researhers recommended the necessity of adopting the integrative technique in designing the objectives and the intended learning outcomes of the handball course for the students specialized in "optional handball" at the Faculty of Physical Education, Al-Azhar University.
\end{abstract}

\section{Introduction:}

$\mathrm{T}$ The world,nowadays,witnesses rapid scientific and technological changes, which entail essential changes in all the life aspects. Consequently, it is of crucial importance to shed light on our educational systems concerning its framework and curricula.

Curriculaof the physical education faculties in general and handball course in particular suffer from extreme variances in the core content of these curriculain the one hand and the wide gap between theory and practice in the other one. These problems entail that the one of the best solutions for the current problems is the integrative course,which aims at overcoming the separationfrom the other fields of knowledge.

Making best use of the integrative course as one of the modern trends in the field of course and instruction may assist greatly in overcoming many problems that emerged on using the other means of designing curricula. The integrative course is considered a middle step between the separation of curricula and the merging of the curricula completely because it takes into consideration the separated curricula and in the same time does pay the due attention when it is necessary to the teaching process.(10 : 91)

Faculties of physical education are considered one of the responsible educational establishments for designing the human cognitively, emotionally and behaviorally through their special programs. As Nolan, Catherine, Veronia (1995) think, They provide many effective programs that help in designing the student teacher experiences and prepare him to meet the needs of work and the positions skillfully and efficiently. (20:30)

The study researcher surveyed the Faculty of Physical Education the curricula at Al-Azhar University with a special focus on the handball course for those students specialized in "optional handball". The results of the survey revealed that the handball course is far away from the integrative trend, which became an essential requisite in the age of information technology. These findings were, also, asserted by the studies of AmenaMostafa Abo Egeila (2007) (4) and Mohammed Abdul Kader Elbaz (2015) (17)who pinpointed out the effectiveness of the integrative course in designing the curricula of the Faculty of Physical Education, which is the main aim of the present study. Moreover, these developmentsencourage us to functionalize many fields of science related to the handball course.

To the best of the researchers' knowledge and afterreviewingthe related literature it is concluded that there is no studies focused in linking the objectives developmentand the intended learning outcomeswith the handball course and the integrative technique. Consequently, it is obvious that there is a dire need for conducting such research in order to develop the 
instructional results and theintended learning outcomesin relation to the course of handball for the students specialized in "optional handball" at the Faculty of Physical Education, Al-Azhar University.This could be conductedin the light of the integrativetechnique, according to scientific basis and the clear objectives thatmust suit the current needs of the society, the new educational trends and the requirements of the labor market.

\section{Aim of the Research:}

The current research aimed at designing the objectives and the intended learning outcomes of the handball course in the light of the integrativetechnique for the students specialized in "optional handball" at the Faculty of Physical Education, Al-Azhar University.

\section{Questions of the Research:}

- Is it possible to form a perspectivefor designing the objectives of the handball course in the light of the integrativetechnique for the students specializedin "optional handball" at the Faculty of Physical Education, Al-Azhar University?

- Is it possible to form a perspective for designing the intended learning outcomes of the handball course in the light of the integrativetechniques for the students specialized in "optional handball" at the Faculty of Physical Education, Al-Azhar University?

\section{Terms of the Study:}

\section{course:}

All the forms of activities and experiences that students engaged in under the supervision and direction of the educational establishment with the aim of helping them to grow and modify their behaviors in the light of the educational intendedgoals. $(1: 20)$

\section{course Development:}

Conducting changes in one item or more of an existent course for designing and updating this course with the new scientific and educational trends and the economic, social and cultural changes to meet the society and it its individuals' needs in the light of the available resources especially time, effort and cost. $(10: 51)$

\section{Integration:}

Presenting knowledge in functional ways to be likesequenced and linked concepts cover different issues without separation or division for knowledge into different fields with the aim of showing the unity of thought and avoiding illogical differentiation and isolation among the fields of knowledge. $(21: 176)$

\section{Procedures of the Study:}

\section{research methodology}

The researchers adopted the descriptive course based on the survey because it is the most appropriate for the nature of the research and its objectives and questions.

\section{Sample of the Research:}

The researcher adopted a deliberate sample consisted of (10 participants) from the experts specialized in course and instruction at the faculties of education in Egypt and the those who responsible for teaching handball curricula from the staff members at the faculties of physical education in Egypt (5 participants) from the experts. Appendix 1.

\section{Data Collecting Tools:}

The researcher designed tools of data collecting after:

\section{- Analyzing Documents and References:}

The researchers analyzed many specialized references and researches in the field of course and instruction to identify the components of the course,objectives selecting standards, basics of course designing and basics of designing course.references(1) (3) (5) (9) (10) (8) (15) (6).

Moreover, the researchers surveyed some scientific references specialized in handball in order to delineate the constructive framework of the handball and the general and specific physical features of the players. Furthermore, through surveying the related literature, they portrayed the technical and instructional skills of the handball basic skills and the international law legislation of handball references (13) (12) (18) (19).

\section{- Personal interviews:}

The researchers conducted many personal interviews with those who specialized in course and instruction and handball in order to benefit from their scientific experiences in designing the research questionnaire, identifying the different sides of the problem, administering the questionnaire, selecting the main dimensions and the sub items.

\section{- Questionnaire:}

The researchers designed the primary from of the questionnaire after identifying the aims of the 
research;more specifically, they analyzed many questionnaires that was adopted in similar studies and identifying the basic dimensions of the questionnaire. The suitable items of every dimension were identified where the primary form of the questionnaire became:

- The first dimension: aims of handball course (14) items.

- The second dimension: the intended learning outcomes (89) items.

The questionnaire was submitted for (10) experts in the field of educational psychology, course and instruction of physical education and handball in order to identify the clearness of the items and their validity for achieving the purpose of the research. The researchersadopted the items that were agreed by (80\%) in the light of the experts feedback. The questionnaire was modified according to the views of experts through omitting, adding and modifying some items and dimensions to be in its final form appendix (2). The final form of the questionnaire consisted of five dimensions:

- The first dimension: general objectives of the handball course (13) items.
- The second dimension: the intended learning outcomes (knowledge and comprehension) (21) items.

- The third dimension: the intended learning outcomes (mental skills) (17) items.

- The fourth dimension: the intended learning outcomes (practical and professional skills) (17) items.

- The fifth dimension: the intended learning outcomes (general and imparted skills) (10) items.

\section{Scientific Factors of the Questionnaire:}

The scientific factors of the questionnaire were:

\section{First: Validity:}

For judging the validity of the questionnaire, the internal consistency techniquewas adopted by the researchers. They calculated the correlation coefficient between the items of the questionnaire and the main dimensions; then, they identified the correlation coefficients between every dimension and the total degree of the questionnaire. Throughthe main dimensions and their items, the validity (correlation coefficient) was calculatedamong each item and its main dimension and the total degree of the questionnaire.

Table (1)

Correlation coefficient between the items and their dimensions $\mathrm{N}=10$

\begin{tabular}{|c|c|c|c|c|c|}
\hline \multirow{2}{*}{$S$} & \multirow{2}{*}{ General objectives of handball } & \multicolumn{4}{|c|}{ Intended learning outcomes } \\
\hline & & Knowledge and comprehension & Mental skills & Professional and Practical skills & General and imparted skills \\
\hline 1 & 0.85 & 0.86 & 0.88 & 0.93 & 0.86 \\
\hline 2 & 0.94 & 0.81 & 0.85 & 0.86 & 0.83 \\
\hline 3 & 0.97 & 0.83 & 0.90 & 0.93 & 0.87 \\
\hline 4 & 0.92 & 0.84 & 0.83 & 0.87 & 0.88 \\
\hline 5 & 0.84 & 0.90 & 0.84 & 0.84 & 0.91 \\
\hline 6 & 0.88 & 0.85 & 0.83 & 0.93 & 0.95 \\
\hline 7 & 0.85 & 0.87 & 0.81 & 0.95 & 0.95 \\
\hline 8 & 0.95 & 0.92 & 0.80 & 0.96 & 0.87 \\
\hline 9 & 0.88 & 0.91 & 0.84 & 0.85 & 0.86 \\
\hline 10 & 0.81 & 0.95 & 0.96 & 0.85 & 0.83 \\
\hline 11 & 0.89 & 0.90 & 0.94 & 0.87 & \\
\hline 12 & 0.91 & 0.95 & 0.85 & 0.91 & \\
\hline 13 & 0.81 & 0.92 & 0.84 & 0.93 & \\
\hline 14 & & 0.81 & 0.96 & 0.80 & \\
\hline 15 & & 0.85 & 0.80 & 0.89 & \\
\hline 16 & & 0.82 & 0.86 & 0.87 & \\
\hline 17 & & 0.90 & 0.83 & 0.83 & \\
\hline 18 & & 0.94 & & & \\
\hline 19 & & 0.95 & & & \\
\hline 20 & & 0.98 & & & \\
\hline 21 & & 0.86 & & & \\
\hline
\end{tabular}

Correlation coefficient at $(0.05)$ level $=0.541$ 
It is clear from table (1) that there is a significant correlation between the items and the total degree of each dimension in the questionnaire, which indicated clearly the validity of the items in representing these dimensions.

Table (2)

Correlation coefficient between the main dimensions and the total degree of the questionnaire

\begin{tabular}{|c|c|c|c|}
\hline S & Dimensions & S & Significance \\
\hline 1 & General aims of handball course & 0.786 & Significant \\
\hline 2 & The intended learning outcomes (knowledge and comprehension) & 0.817 & Significant \\
\hline 3 & The intended learning outcomes (mental skills) & 0.832 & Significant \\
\hline 4 & The intended learning outcomes (practical and professional skills). & 0.761 & Significant \\
\hline 5 & The intended learning outcomes (general and imparted skills). & 0.785 & Significant \\
\hline
\end{tabular}

Correlation coefficient at $(0.05)$ level $=0.541$

It is clear from table (2) that there is a significant correlation between each dimension and the total degree of the questionnaire, which revealed the validity of the dimensions in representing the total degree of the questionnaire.

\section{Second: Reliability}

The spilt half technique and Cronbach's alpha for the odd items and the total degree were adopted for identifying the reliability coefficient. These techniques depend greatly on the homogeneity of the adopted tool degrees.

Table (3)

Reliability coefficient of the questionnaire (under investigation) $\mathrm{N}=10$

\begin{tabular}{|c|c|c|c|c|}
\hline $\mathrm{S}$ & Dimensions & $\begin{array}{l}\text { Total } \\
\text { item }\end{array}$ & $\begin{array}{l}\text { Correlation coefficient (spilt } \\
\text { half ) }\end{array}$ & $\begin{array}{l}\text { Cronbach's alpha } \\
\text { coefficient }\end{array}$ \\
\hline 1 & General aims of handball course & 13 & 0.781 & 0.782 \\
\hline 2 & $\begin{array}{l}\text { The intended learning outcomes (knowledge and } \\
\text { comprehension) }\end{array}$ & 21 & 0.715 & 0.709 \\
\hline 3 & The intended learning outcomes (mental skills) & 17 & 0.894 & 0.901 \\
\hline 4 & $\begin{array}{c}\text { The intended learning outcomes (practical and } \\
\text { professional skills). }\end{array}$ & 17 & 0.762 & 0.775 \\
\hline 5 & $\begin{array}{l}\text { The intended learning outcomes (general and imparted } \\
\text { skills). }\end{array}$ & 10 & 0.885 & 0.891 \\
\hline 6 & Total questionnaire & 78 & 0.858 & 0.861 \\
\hline
\end{tabular}

Tabular (r) at (0.05) level $=0.541$

It is clear from table (3) that Correlation coefficient via spilt half ranged from ( 0.715$)$ to ( 0.894$)$ and Cronbach's alpha coefficient ranged from ( 0.709$)$ to ( 0.901$)$ which indicated the reliability and applicability of the questionnaire.

\section{Administration of the research:}

The questionnaire was administered to the research sample fromTuesday 15/9/2015 A.C. till Sunday 29/11/2015 A.C.The primary form of the questionnaire was submitted for the jury from Tuesday 15/9/2015 A.C. till Tuesday $15 / 10 / 2015$ A.C. the final form of the questionnaire was administered from Saturday 17/10/2015 A.C. till 29/11/2015 A.C. 


\section{First: results}

Table (4)

designing the general objectives of the handball course $n=15$

\begin{tabular}{|c|c|c|c|c|c|c|c|c|c|}
\hline \multirow{2}{*}{ S } & \multirow{2}{*}{ Items } & \multicolumn{2}{|c|}{ Agree } & \multicolumn{2}{|c|}{$\begin{array}{l}\text { To some } \\
\text { extent }\end{array}$} & \multicolumn{2}{|c|}{ Disagree } & \multirow{2}{*}{$\begin{array}{c}\text { Estimated } \\
\text { Degree }\end{array}$} & \multirow{2}{*}{ Percentage } \\
\hline & & $\mathrm{F}$ & $\%$ & $\mathrm{~F}$ & $\%$ & F & $\%$ & & \\
\hline & $\begin{array}{l}\text { Preparingthe student teacher who realizes the educational, } \\
\text { physical, psychological importance of practicing handball. }\end{array}$ & 14 & 93.33 & 1 & 6.67 & - & - & 44 & 97.78 \\
\hline & $\begin{array}{l}\text { Preparing the student teacher who is able to develop the } \\
\text { general and the special physical fitnesscomponents of the } \\
\text { handball. }\end{array}$ & 13 & 86.67 & 1 & 6.67 & 1 & 6.67 & 42 & 93.33 \\
\hline & $\begin{array}{l}\text { Preparing the student teacher who is able to Learn and teach } \\
\text { thehandball kinetic skills whether attack or defense, playing } \\
\text { ways,figuration and duties of attack and defense positions. }\end{array}$ & 13 & 86.67 & 1 & 6.67 & 1 & 6.67 & 42 & 93.33 \\
\hline & $\begin{array}{l}\text { Preparing the student teacher who is able to make use of the } \\
\text { different strategies and methods of teaching. }\end{array}$ & 12 & 80.00 & 2 & 13.33 & 1 & 6.67 & 41 & 91.11 \\
\hline & $\begin{array}{l}\text { Acquiring the student teacher the power of functionalizing } \\
\text { the instructional media in learning handball skills. }\end{array}$ & 13 & & 2 & 13.33 & - & - & 43 & 95.56 \\
\hline & $\begin{array}{l}\text { Acquiring the student teacher the power of implementing } \\
\text { the modern technologies in planning, implementing and } \\
\text { evaluating handball skills in the physical education lessons. }\end{array}$ & 13 & 86.67 & 2 & 13.33 & - & - & 43 & 95.56 \\
\hline & $\begin{array}{l}\text { Preparing the student teacher who realizes the security and } \\
\text { safety measures in the handball playground. }\end{array}$ & 12 & 80.00 & 2 & 13.33 & 1 & 6.67 & 41 & 91.11 \\
\hline & $\begin{array}{l}\text { Preparing the student teacher who is able to Lead the } \\
\text { handball team (before- during- after) the match. }\end{array}$ & 12 & 80.00 & 2 & 13.33 & 1 & 6.67 & 41 & 91.11 \\
\hline & $\begin{array}{l}\text { Preparing the student teacher who is able to Analyze and } \\
\text { interpre the international law legislations of the handball } \\
\text { and refereeing matches. }\end{array}$ & 11 & 73.33 & 3 & 20.00 & 1 & 6.67 & 40 & 88.89 \\
\hline & $\begin{array}{l}\text { Preparing the student teacher who is able to Find out } \\
\text { talented students and encouraging them to practice } \\
\text { handball. }\end{array}$ & 12 & 80.00 & 2 & 13.33 & 1 & 6.67 & 41 & 91.11 \\
\hline & $\begin{array}{l}\text { Preparing the student teacher who is able to Follow up, } \\
\text { evaluate, develop the handball course and assuring the } \\
\text { achievement of its objectives. }\end{array}$ & 13 & 86.67 & 1 & 6.67 & 1 & 6.67 & 42 & 93.33 \\
\hline & $\begin{array}{l}\text { Acquiring thestudent teacher the powerof observing and } \\
\text { planning, criticizing, comparing and scientific deduction . }\end{array}$ & 12 & 80.00 & 2 & 13.33 & 1 & 6.67 & 41 & 91.11 \\
\hline & $\begin{array}{l}\text { Acquiring the student teacher the power of Implementing } \\
\text { the related sciences with the handball for achieving the } \\
\text { unity and integration of knowledge. }\end{array}$ & 12 & 80.00 & 2 & 13.33 & 1 & 6.67 & 41 & 91.11 \\
\hline
\end{tabular}


Table (5)

(knowledge and comprehension)

\begin{tabular}{|c|c|c|c|c|c|c|c|c|c|}
\hline \multirow{2}{*}{ S } & \multirow{2}{*}{ Items } & \multicolumn{2}{|c|}{ Agree } & \multicolumn{2}{|c|}{$\begin{array}{c}\text { To some } \\
\text { extent }\end{array}$} & \multicolumn{2}{|c|}{ Disagree } & \multirow{2}{*}{$\begin{array}{l}\text { Estimated } \\
\text { Degree }\end{array}$} & \multirow[t]{2}{*}{ Percentage } \\
\hline & & F & $\%$ & $\mathrm{~F}$ & $\%$ & $\mathrm{~F}$ & $\%$ & & \\
\hline & $\begin{array}{c}\text { Preparing the student teacher who is able toIdentify the most } \\
\text { important physical fitness and kinetic exercises in handball and } \\
\text { how to be applied. }\end{array}$ & 14 & 93.33 & 1 & 6.67 & - & - & 44 & 97.78 \\
\hline & $\begin{array}{l}\text { Preparing the student teacher who is able to Detect the } \\
\text { relationship between handball and the surrounding environment. }\end{array}$ & 14 & 93.33 & - & - & 1 & 6.67 & 43 & 95.56 \\
\hline & $\begin{array}{l}\text { Preparing the student teacher who is able to Understand the } \\
\text { educational valuesand the outcomes of practicing handball. }\end{array}$ & 13 & 86.67 & 1 & 6.67 & 1 & 6.67 & 42 & 93.33 \\
\hline & $\begin{array}{l}\text { Preparing the student teacher who is able to Identify the signs and } \\
\text { special terms of handball. }\end{array}$ & 10 & 66.67 & 3 & 20.00 & 2 & 13.33 & 38 & 84.44 \\
\hline & $\begin{array}{l}\text { Preparing the student teacher who is able to Realize the handball } \\
\text { general and special physical requirements. }\end{array}$ & 10 & 66.67 & 4 & 26.67 & 1 & 6.67 & 39 & 86.67 \\
\hline & $\begin{array}{l}\text { Preparing the student teacher who is able to Understand the most } \\
\text { important preparatory games in handball. }\end{array}$ & 11 & 73.33 & 3 & 20.00 & 1 & 6.67 & 40 & 88.89 \\
\hline & $\begin{array}{l}\text { Preparing the student teacher who is able to Portray the } \\
\text { performance of the basic skills in handball. }\end{array}$ & 12 & 80.00 & 2 & 13.33 & 1 & 6.67 & 41 & 91.11 \\
\hline & $\begin{array}{l}\text { Preparing the student teacher who is able to Mention the } \\
\text { instructional steps, the technical skills, the practical exercises, } \\
\text { and the common errors in performing the basic skills in handball. }\end{array}$ & 12 & 80.00 & 2 & 13.33 & 1 & 6.67 & 41 & 91.11 \\
\hline & $\begin{array}{l}\text { Preparing the student teacher who is able to Describ the stages of } \\
\text { learning the attacking skills in handball. }\end{array}$ & 12 & 80.00 & 2 & 13.33 & - & - & 41 & 91.11 \\
\hline & $\begin{array}{l}\text { Preparing the student teacher who is able to Define the most } \\
\text { important distinguishing psychological skills of the players' } \\
\text { positions in handball. }\end{array}$ & 13 & 86.67 & 2 & 13.33 & - & - & 43 & 95.56 \\
\hline & $\begin{array}{l}\text { Preparing the student teacher who is able to Identify the } \\
\text { instructional steps, the technical skills, the practical exercises, } \\
\text { and the common errors of the players' positions in handball. }\end{array}$ & 13 & 86.67 & 2 & 13.33 & - & - & 43 & 95.56 \\
\hline & $\begin{array}{l}\text { Preparing the student teacher who is able to Identify the sequence } \\
\text { in leaning the basic skills in handball. }\end{array}$ & 12 & 80.00 & 2 & 13.33 & 1 & 6.67 & 41 & 91.11 \\
\hline & $\begin{array}{l}\text { Preparing the student teacher who is able to Delineate the } \\
\text { necessary special conditions for learning the basic skills in } \\
\text { handball. }\end{array}$ & 11 & 73.33 & 3 & 20.00 & 1 & 6.67 & 40 & 88.89 \\
\hline & $\begin{array}{l}\text { Preparing the student teacher who is able to Portray the suitable } \\
\text { teaching methods and techniques for learning the basic skills in } \\
\text { handball. }\end{array}$ & 13 & 86.67 & 2 & 13.33 & - & - & 43 & 95.56 \\
\hline & $\begin{array}{l}\text { Preparing the student teacher who is able to Recognize the } \\
\text { instructional media role in learning the basic skills in hand ball. }\end{array}$ & 12 & 80.00 & 2 & 13.33 & 1 & 6.67 & 41 & 91.11 \\
\hline & $\begin{array}{l}\text { Preparing the student teacher who is able to Identify the } \\
\text { approaches of leading the handball team (before- during- after) } \\
\text { the match. }\end{array}$ & 11 & 73.33 & 3 & 20.00 & 1 & 6.67 & 40 & 88.89 \\
\hline & $\begin{array}{l}\text { Preparing the student teacher who is able to Recognize the } \\
\text { emergence and history of the handball. }\end{array}$ & 13 & 86.67 & 2 & 13.33 & - & - & 43 & 95.56 \\
\hline & $\begin{array}{l}\text { Preparing the student teacher who is able to Identify the means of } \\
\text { evaluating and measuring the physical, behavioral and } \\
\text { psychological requirements from the players of the handball }\end{array}$ & 11 & 73.33 & 3 & 20.00 & 1 & 6.67 & 40 & 88.89 \\
\hline & $\begin{array}{l}\text { Preparing the student teacher who is able to Identify the } \\
\text { international laws legislations in handballand how to be applied. }\end{array}$ & 11 & 73.33 & 3 & 20.00 & 1 & 6.67 & 40 & 88.89 \\
\hline & $\begin{array}{c}\text { Preparing the student teacher who is able to Realizethe safety and } \\
\text { security measures that should be existed in the } \\
\text { handballplaygrounds. }\end{array}$ & 13 & 86.67 & 2 & 13.33 & - & - & 43 & 95.56 \\
\hline & $\begin{array}{c}\text { Preparing the student teacher who is able to Detect the most } \\
\text { important related sciences to the handball and ways of } \\
\text { implementingthem. }\end{array}$ & 11 & 73.33 & 3 & 20.00 & 1 & 6.67 & 40 & 88.89 \\
\hline
\end{tabular}


Table (6)

(The mental skills)

\begin{tabular}{|c|c|c|c|c|c|c|c|c|c|}
\hline \multirow[t]{2}{*}{ S } & \multirow{2}{*}{ Items } & \multicolumn{2}{|c|}{ Agree } & \multicolumn{2}{|c|}{$\begin{array}{l}\text { To some } \\
\text { extent }\end{array}$} & \multicolumn{2}{|c|}{ Disagree } & \multirow{2}{*}{$\begin{array}{l}\text { Estimated } \\
\text { Degree }\end{array}$} & \multirow[t]{2}{*}{ Percentage } \\
\hline & & $\mathrm{F}$ & $\%$ & $\mathrm{~F}$ & $\%$ & $\mathrm{~F}$ & $\%$ & & \\
\hline & $\begin{array}{l}\text { Preparing the student teacher who is able to Distinguish } \\
\text { signs and terms associated with the handball. }\end{array}$ & 12 & 82.00 & 2 & 13.33 & 1 & 6.67 & 41 & 91.11 \\
\hline & $\begin{array}{l}\text { Preparing the student teacher who is able to Distinguish } \\
\text { betweenthe basic skills in handball, whether they are } \\
\text { performed with or without the ball. }\end{array}$ & 13 & 86.67 & 2 & 13.33 & - & - & 43 & 95.56 \\
\hline & $\begin{array}{l}\text { Preparing the student teacher who is able to Analyze the } \\
\text { technical steps in performing the basic skills (attacking- } \\
\text { defensing- goal keeping) in handball. }\end{array}$ & 13 & 86.67 & 2 & 13.33 & - & - & 43 & 95.56 \\
\hline & $\begin{array}{l}\text { Preparing the student teacher who is able to Identify the } \\
\text { common errors in performing the basic skills in handball } \\
\text { and correcting them. }\end{array}$ & 12 & 82.00 & 2 & 13.33 & 1 & 6.67 & 41 & 91.11 \\
\hline & $\begin{array}{l}\text { Preparing the student teacher who is able to Innovate new } \\
\text { exercises related to the handball beginner learners. }\end{array}$ & 12 & 82.00 & 3 & 20.00 & - & - & 42 & 93.33 \\
\hline & $\begin{array}{l}\text { Preparing the student teacher who is able to Innovatesome } \\
\text { small games associated with the attacking movements in } \\
\text { handball. }\end{array}$ & 12 & 82.00 & 2 & 13.33 & 1 & 6.67 & 41 & 91.11 \\
\hline & $\begin{array}{l}\text { Preparing the student teacher who is able to discuss the } \\
\text { handball international law elements. }\end{array}$ & 10 & 66.67 & 2 & 13.33 & 3 & 20.00 & 37 & 82.22 \\
\hline & $\begin{array}{l}\text { Preparing the student teacher who is able to Select the most } \\
\text { suitable methods of teaching for learning the basic skills in } \\
\text { handball. }\end{array}$ & 11 & 73.33 & 2 & 13.33 & 2 & 13.33 & 39 & 86.67 \\
\hline & $\begin{array}{l}\text { Preparing the student teacher who is able to Realize the } \\
\text { importance of functionalizing the handball related sciences } \\
\text { in planning, implementing, standardizing, evaluating the } \\
\text { content of the educational module. }\end{array}$ & 12 & 82.00 & 2 & 13.33 & 1 & 6.67 & 41 & 91.11 \\
\hline & $\begin{array}{l}\text { Preparing the student teacher who is able to Distinguish } \\
\text { between the technical and the legal errors of the players' } \\
\text { performancein handball skills. }\end{array}$ & 12 & 82.00 & 2 & 13.33 & 1 & 6.67 & 41 & 91.11 \\
\hline & $\begin{array}{l}\text { Preparing the student teacher who is able to Analyzethe } \\
\text { handball matches for presenting the advantages and } \\
\text { disadvantages of the players' performancein handball. }\end{array}$ & 11 & 73.33 & 2 & 13.33 & 2 & 13.33 & 39 & 86.67 \\
\hline & $\begin{array}{l}\text { Preparing the student teacher who is able to Realize the } \\
\text { importance of the group and the individual workof the } \\
\text { players' performance in handball. }\end{array}$ & 12 & 82.00 & 2 & 13.33 & 1 & 6.67 & 41 & 91.11 \\
\hline & $\begin{array}{l}\text { Preparing the student teacher who is able to Delineate the } \\
\text { most important working muscles during performing the } \\
\text { handball and how could they be developed. }\end{array}$ & 12 & 82.00 & 2 & 13.33 & 1 & 6.67 & 41 & 91.11 \\
\hline & $\begin{array}{l}\text { Preparing the student teacher who is able to Identify the } \\
\text { most important measurements and the distinguishing boy } \\
\text { movements of the handballplayers. }\end{array}$ & 14 & 93.33 & 1 & 6.67 & - & - & 44 & 97.78 \\
\hline & $\begin{array}{l}\text { Preparing the student teacher who is able to Distinguish } \\
\text { between the chores of the attackers and the defenders in } \\
\text { handball. }\end{array}$ & 12 & 82.00 & 2 & 13.33 & 1 & 6.67 & 41 & 91.11 \\
\hline & $\begin{array}{l}\text { Preparing the student teacher who is able to Identify the } \\
\text { components of the healthyhandball playerfood. }\end{array}$ & 11 & 73.33 & 3 & 20.00 & 1 & 6.67 & 40 & 88.89 \\
\hline & $\begin{array}{l}\text { Preparing the student teacher who is able to Analyze the } \\
\text { results of the assessment and evaluation of the physical and } \\
\text { behavioral requirements in handball for increasing the } \\
\text { effectiveness of the educational process. }\end{array}$ & 12 & 82.00 & 2 & 13.33 & 1 & 6.67 & 41 & 91.11 \\
\hline
\end{tabular}


Table (7)

(The practical and professional skills)

\begin{tabular}{|c|c|c|c|c|c|c|c|c|c|}
\hline \multirow[t]{2}{*}{ S } & \multirow{2}{*}{ Items } & \multicolumn{2}{|c|}{ Agree } & \multicolumn{2}{|c|}{$\begin{array}{c}\text { To some } \\
\text { extent }\end{array}$} & \multicolumn{2}{|c|}{ Disagree } & \multirow{2}{*}{$\begin{array}{l}\text { Estimated } \\
\text { Degree }\end{array}$} & \multirow[t]{2}{*}{ Percentage } \\
\hline & & $\mathrm{F}$ & $\%$ & $\mathrm{~F}$ & $\%$ & $\mathrm{~F}$ & $\%$ & & \\
\hline & $\begin{array}{l}\text { Preparing the student teacher who is able to Acquire the } \\
\text { preparatory and complete harmony with the basic skills } \\
\text { in handball. }\end{array}$ & 12 & 80.00 & 2 & 13.33 & 1 & 6.67 & 41 & 91.11 \\
\hline & $\begin{array}{l}\text { Preparing the student teacher who is able to Have the } \\
\text { ability to develop and improve the general and the } \\
\text { specific physical requirementsin handball. }\end{array}$ & 12 & 80.00 & 2 & 13.33 & 1 & 6.67 & 41 & 91.11 \\
\hline & $\begin{array}{l}\text { Preparing the student teacher who is able to Functionalize } \\
\text { the instructional media on learning the basic skillsin } \\
\text { handball. }\end{array}$ & 15 & 100.00 & - & - & - & - & 45 & 100.00 \\
\hline & $\begin{array}{l}\text { Preparing the student teacher who is able to Have the } \\
\text { ability to learn the basic skills required for the } \\
\text { beginnersin handball. }\end{array}$ & 11 & 73.33 & 2 & 13.33 & 2 & 13.33 & 39 & 86.67 \\
\hline & $\begin{array}{l}\text { Preparing the student teacher who is able to Usesigns and } \\
\text { the scientific terms when learning the basic skillsin } \\
\text { handball. }\end{array}$ & 12 & 80.00 & 3 & 20.00 & - & - & 43 & 95.56 \\
\hline & $\begin{array}{l}\text { Preparing the student teacher who is able to Pay attention } \\
\text { for the security and safety measures in the in } \\
\text { handballplayground. }\end{array}$ & 12 & 80.00 & 1 & 6.67 & 2 & 13.33 & 40 & 88.89 \\
\hline & $\begin{array}{l}\text { Preparing the student teacher who is able to Interpret the } \\
\text { items of the handball international law in the educational } \\
\text { situation. }\end{array}$ & 12 & 80.00 & 2 & 13.33 & 1 & 6.67 & 41 & 91.11 \\
\hline & $\begin{array}{l}\text { Preparing the student teacher who is able to Use the } \\
\text { helping tools and devices when learning the basic skills } \\
\text { in handball. }\end{array}$ & 12 & 80.00 & 3 & 20.00 & - & - & 43 & 95.56 \\
\hline & $\begin{array}{l}\text { Preparing the student teacher who is able to Have the } \\
\text { ability to refereeing the handball matches. }\end{array}$ & 14 & 93.33 & 1 & 6.67 & - & - & 44 & 9.78 \\
\hline & $\begin{array}{l}\text { Preparing the student teacher who is able to Master the } \\
\text { basic handball skills performance in the learning } \\
\text { situations. }\end{array}$ & 12 & 80.00 & 2 & 13.33 & 1 & 6.67 & 41 & 91.11 \\
\hline & $\begin{array}{l}\text { Preparing the student teacher who is able to Apply the } \\
\text { game plansin handball. }\end{array}$ & 10 & 66.67 & 1 & 6.67 & 4 & 26.67 & 36 & 80.00 \\
\hline & $\begin{array}{l}\text { Preparing the student teacher who is able to Design, plan, } \\
\text { implement, and evaluate the instructional Modules in } \\
\text { handball. }\end{array}$ & 12 & 80.00 & 2 & 13.33 & 1 & 6.67 & 41 & 91.11 \\
\hline & $\begin{array}{l}\text { Preparing the student teacher who is able to Administer } \\
\text { the means of assessment and evaluationin handball. }\end{array}$ & 12 & 80.00 & 2 & 13.33 & 1 & 6.67 & 41 & 91.11 \\
\hline & $\begin{array}{l}\text { Preparing the student teacher who is able to Have the } \\
\text { ability to maintain the devices and tools used in } \\
\text { practicing the handball skills . }\end{array}$ & 12 & 80.00 & 2 & 13.33 & 1 & 6.67 & 39 & 86.67 \\
\hline & $\begin{array}{c}\text { Preparing the student teacher who is able to Design and } \\
\text { innovate devices, educational means and specific } \\
\text { exercises that can be used in the educational units in } \\
\text { handball }\end{array}$ & 11 & 73.33 & 2 & 13.33 & 2 & 13.33 & 41 & 91.11 \\
\hline & $\begin{array}{l}\text { Preparing the student teacher who is able to Find out the } \\
\text { talented students in handball and encouraging them to } \\
\text { practice it. }\end{array}$ & 12 & 80.00 & 2 & 13.33 & 1 & 6.67 & 41 & 91.11 \\
\hline & $\begin{array}{l}\text { Preparing the student teacher who is able to Design the } \\
\text { specialized programs in designing the talented abilities in } \\
\text { handball. }\end{array}$ & 12 & 80.00 & 2 & 13.33 & 1 & 6.67 & 41 & 91.11 \\
\hline
\end{tabular}


Table (8)

(The general and the imparted skills)

\begin{tabular}{|c|c|c|c|c|c|c|c|c|c|}
\hline \multirow{2}{*}{ S } & \multirow{2}{*}{ Items } & \multicolumn{2}{|c|}{ Agree } & \multicolumn{2}{|c|}{$\begin{array}{l}\text { To some } \\
\text { extent }\end{array}$} & \multicolumn{2}{|c|}{ Disagree } & \multirow{2}{*}{$\begin{array}{l}\text { Estimated } \\
\text { Degree }\end{array}$} & \multirow[t]{2}{*}{ Percentage } \\
\hline & & $\mathrm{F}$ & $\%$ & F & $\%$ & F & $\%$ & & \\
\hline & $\begin{array}{l}\text { Preparing the student teacher who is able to Manage and } \\
\text { lead his friends during the educational situations in } \\
\text { handball. }\end{array}$ & 12 & 80.00 & 2 & 13.33 & 1 & 6.67 & 41 & 91.11 \\
\hline & $\begin{array}{l}\text { Preparing the student teacher who is able to Use the new } \\
\text { methods of communications and the new technologies in } \\
\text { handball. }\end{array}$ & 13 & 86.67 & 1 & 6.67 & 1 & 6.67 & 42 & 93.33 \\
\hline & $\begin{array}{l}\text { Preparing the student teacher who is able to Continueself- } \\
\text { learning in handball through different resources } \\
\text { (references, scientific magazines, researches, the world } \\
\text { wide web, ...). }\end{array}$ & 13 & 13.33 & 2 & 13.33 & - & - & 43 & 95.56 \\
\hline & $\begin{array}{l}\text { Preparing the student teacher who is able to Interact with } \\
\text { what will arise concerning methods of teaching and } \\
\text { training and the sport management in handball . }\end{array}$ & 11 & 73.33 & 2 & 13.33 & 2 & 13.33 & 39 & 86.67 \\
\hline & $\begin{array}{l}\text { Preparing the student teacher who is able to Lead, } \\
\text { cooperative work and positive interaction with learners. }\end{array}$ & 14 & 93.33 & 1 & 6.67 & - & - & 44 & 97.8 \\
\hline & $\begin{array}{l}\text { Preparing the student teacher who is able to Make use of } \\
\text { modern technological means in handball. }\end{array}$ & 12 & 80.00 & 2 & 13.33 & 1 & 6.67 & 41 & 91.11 \\
\hline & $\begin{array}{c}\text { Preparing the student teacher who is able to Select the } \\
\text { most suitable methods, means, devices and tools that } \\
\text { sustain in designing the physical and behavioral } \\
\text { performance in handball . }\end{array}$ & 15 & 100.00 & - & - & - & - & 45 & 100.00 \\
\hline & $\begin{array}{l}\text { Preparing the student teacher who is able to Participatein } \\
\text { the professional activities of the physical education that } \\
\text { include training courses, refereeing, playground injuries } \\
\text { and the natural treatment. }\end{array}$ & 12 & 80.00 & 2 & 13.33 & 1 & 6.67 & 41 & 91.11 \\
\hline & $\begin{array}{l}\text { Preparing the student teacher who is able to Develop time } \\
\text { management during implementing the instructional } \\
\text { modules and taking into consideration the time } \\
\text { distribution of the handball course. }\end{array}$ & 12 & 80.00 & 2 & 13.33 & 1 & 6.67 & 41 & 91.11 \\
\hline & $\begin{array}{l}\text { Preparing the student teacher who is able to Adopt the } \\
\text { scientific means of thought and the speed of decision to } \\
\text { select the most appropriate solutions for problems related } \\
\text { to the educational situations in handball. }\end{array}$ & 10 & 66.67 & 2 & 13.33 & 3 & 20.00 & 37 & 82.22 \\
\hline
\end{tabular}

\section{Second: Discussion of Results:}

From the above mentioned results attained by the researchers, these results could be interpreted as follows:

It is clear from table (4) that the highest items in relation to their percentages were the items $(1,5,6)$ stated that "Preparing the student teacher who realizes the educational, physical, psychological importance of practicing handball ", "Acquiring the student teacher the power of functionalizing the instructional media in learning handball skills "and "Acquiring the student teacher the power of implementing the modern technologies in planning, implementing and evaluating handball skills in the physical education lessons "With a percentage estimated $(97.78 \%, 95.56 \%, 95.56 \%)$ which is significant in favor of the response "agree ",The researchers pinpointed that the educational and psychological importance in practicing the handball isconsidered one of the most important value that should be implanted in the beginners and specialists in handball as it represents an educational value aims at forming new integrated, psychologically stable and well-built physically. Moreover, enabling the student to have the ability to implement the modern technologies helps greatly in increasing the effectiveness of the lesson and enables the learner to have the ability to innovate and invest the available resources. The technological means may also help in saving time and effort and attracting the attentions of the students in relation to what is provided. Moreover, the technological means helps in overcoming boredom and monotony during the lesson. On the other hand the least item with percentage was the item ( 9 ) stated that "Preparing the student teacher who is able to Analyze and interpret the international law legislations of the handball and refereeing matches" with percentage ( $88.89 \%$ ) which is significant in favor of the response " agree ", The 
researchers suggested that analyzing and interpreting the international law legislations and refereeing matches are more specialized and advanced skills that acquired through practicing and exercising.

It is clear from table (5) that the highest items in relation to their percentages was the item ( 5) stated that "Preparing the student teacher who is able to Realize the handball general and special physical requirements" With a percentage estimated ( $97.78 \%$ ) which is significant in favor of the response " agree ", The researcher asserted that physical fitness, kinetic exercises of the handball players and how to be applied are of the most important pillars in the educational process. On the other hand the least item with percentage was the item ( 4 ) stated that "Preparing the student teacher who is able to Identify the signs and special terms of handball "with percentage ( $84.44 \%$ ) which is significant in favor of the response " agree ".

It is clear from table (6) that the highest items in relation to their percentages was the item ( 14 ) stated that "Preparing the student teacher who is able to Identify the most important measurements and the distinguishing boy movements of the handball players "With a percentage estimated ( $97.78 \%$ ) which is significant in favor of the response " agree ", The Researchers indicated that studying tests and measurements help the students to acquire the ability of identifying the measurements and the body movements that distinguish the handball players ,On the other hand the least item with percentage was the item ( 7 ) stated that "Preparing the student teacher who is able to discuss the handball international law elements " with percentage ( $82.22 \%$ ) which is significant in favor of the response " agree"

It is clear from table (7) that the highest items in relation to their percentages was the item ( 3 ) stated that "Preparing the student teacher who is able to Functionalize the instructional media on learning the basic skills in handball "With a percentage estimated ( $100 \%$ ) which is significant in favor of the response " agree ", The researchers confirmed that using the instructional media on learning the basic skills in handball is very important in urging the students to learn. On the other hand the least item with percentage was the item ( 11 ) stated that " Preparing the student teacher who is able to Apply the game plans in handball "with percentage ( $80 \%$ ) which is significant in favor of the response "agree".

It is clear from table (8) that the highest items in relation to their percentages was the item ( 7 ) stated that "Preparing the student teacher who is able to Select the most suitable methods, means, devices and tools that sustain in designing the physical and behavioral performance in handball "With a percentage estimated ( $100 \%$ ) which is significant in favor of the response " agree ", The researchers indicated that the best use of methods and means in explaining a lesson help in increasing the speed of learning. Consequently, the best benefit and the greatest outcome could be achieved. On the other hand the least item with percentage was the item ( 10 ) stated that "Preparing the student teacher who is able to Adopt the scientific means of thought and the speed of decision to select the most appropriate solutions for problems related to the educational situations in handball " with percentage ( $82.22 \%$ ) which is significant in favor of the response " agree".

\section{Conclusions:}

In the light of the research aims and the presentation and interpretation of the results as well as the sample of the study the following conclusionswere revealed:

1- The educational, psychological, physical importance ofthe handball is one of the items that should be implanted in the beginners and specialists as this value represents an educational side responsible for preparing integrated and physically and psychologically sound generation.

2- Physical fitness and kinetic exercises of the handball players, and how they are applied are of the main pillars in the educational system.

3- Surveying studies and scales helps the student teacher to identify the measurements and the body movements that distinguish the handball players.

4- Instructional media have an importance in learning the basic skills in handball and in encouraging the students to learn.

5- The best selection of the methods and means used in lessons help in increasing the pace of learning; consequently, achieving the best benefits and the highest profits.

\section{Recommendations:}

In the light of the results attained by the current research, the researchers recommended the following:

1- Adopting the integrative technique in designing and designing the theoretical and practical subjects at the Faculty of Physical Education, Al Azhar University.

2- designing and modifying the intended learning outcomes and objectives in the handball course for the students specialized in "optional handball" at the Faculty 
of Physical Education, Al Azhar University when it is necessary.

3- Providing the necessary human and material resources for achieving the maximum benefits of designing the aims and the intended learning outcomes of the handball course for the students specialized in "optional handball" at the Faculty of Physical Education, Al Azhar University.

\section{References}

1- Abo Al Nga Ahmed Ezz Ed Deen (2003): course in Physical Education (normal - special needs), Dar $\mathrm{Al}$ Asdika, Mansoura.

2- Adnan Darwish, Ameen Al kholy and Mahmoud Anan (1994): Physical Education in School - Practical Education Guide for Teacher and Student, 3rd Ed, Dar Al Fikr Al Arabi , Cairo.

3- Ameen Anwar Al Kholy and Gamal Ed Deen Al Shafeay (2000): Contemporary Physical Education Curricula,Dar Al Fikr Al Arabi, Cairo.

4- Amena Mostafa Abo Ogyla (2007): designing the kinetic expression course in the light of the integrative perspective at the faculty of Physical Education in Oyia, Libya, Unpublished Ph.D. Dissertation, Faculty of Physical Education for Girls, Alexandria.

5- Bodor Al Motawaa and SohairBadr (2006): Physical Education and its Curricula and Methods of Teaching, 2nd Ed, The book Center for Publishing, Cairo.

6- Bucher C.A. (1992): physical education FOR course, the Florida state university.

7- Eman Mohamed Abd Allah (2004): An analytical study of the objectives of Physical Education course during the elementary stage, unpublished Master's Thesis, Faculty of Physical Education, Tanta University.

8- Fathy Yosef Mabrouk (1995): The Integrative Technique in designing course (Theory and Application), 3rd Ed, Dar Al Maaref, Cairo.

9- Helmy Ahmed Al Wakeel (2008): designing Curricula: Reasons, Techniques, Steps, and Obstacles , Dar Al Fikr Al Arabi , Cairo.

10- Hamdy Mohamed Abd El Fattah (2010): The Scientific and Technical Views in Designing, Planning and Implementing Physical Education Curricula, Part 2, Physical Education Library, Al Mansoura.
11- Ibrahim Mohamed Al Shafey (1996): The School course from a New Perspective, Al Obikan Library, Riyadh.

12- Kamal Abd El Hamid Ismaeel and Mohamed SobhyHassanin (2002): Quadripartite of the modern handball "Battery of Assessment in Handball" Scales of Evaluating Performance, 3rd Part, The book Center for Publishing, Cairo.

13- Kamal Ed DeenDarweesh, KadryMorsi and Emad Ed DeenAboo Zaid (2002): Assessment, Evaluation and Analyzing Match in Handball "Theories and Application" , The book Center for Publishing, Cairo.

14- Kawther Hussin Kogak (1997): New Trends in course and Methods of Teaching, 2nd Ed, World of the Books , Cairo.

15- Laila Abdul Hamid Zhran (2006): The Scientific and Technical Foundations in Designing course in Physical Education, 2nd Ed, Dar Zahran , Cairo.

16- Magdy Aziz Ibrahim (2001): Future Perspectives in Updating the System of Learning, The Egyptian Anglo Library, Cairo.

17- Mohamed Abdul Kader Al Baz (2015): designing the content of the football course of for the Faculty of Physical Education students in the light of the integrative perspective and standards of Quality, Unpublished Master's Thesis, Faculty of Physical Education, Al Mansoura University.

18- Mohamed Khaled Hamouda and Galal Kamal Salem (2008): Attack and Defense in Handball , Dar Al Fikr Al Arabi , Cairo.

19- Moneer Gergs Ibrahim (2004): Handball for All "The Comprehensive Training and The Behavioral Excellence" , Dar Al Fikr Al Arabi, Cairo.

20- Nolan, Catherine, veronica (1995): changes in physical education teacher effectiveness as a function of experience, vol. 2 , dissertation abstract international.

21- Roshdy Labib and FayzMeena (1993): Issues in Education course, the Egyptian Anglo Library, Cairo.

22- Soliman Ali Hassan (1993): The Training and Planning Principles in Handball, Dar Al Kotob For Printing and Publishing, Al Mawsel University.

23- Zainb Amr and Gada Abdul Kareem (2008): Methods of Teaching Physical Education, The Theoretical Basis and the Practical Applications, Dar Al Fikr Al Arabi , Cairo. 